\title{
The Effects of Regulatory Quality on the Pro-Cyclicality of Fiscal Policy in Countries in the Central African Economic and Monetary Community (CA EMC)
}

\author{
Jean Roméo Félix Kouika Bouanza, Ted Cléophane Ngassa, Mathias Marie Adrien Ndinga* \\ Department of Economics, Marien Ngouabi University and LARES, Brazzaville, Republic of Congo \\ Email: *mathias.ndinga@umng.cg
}

How to cite this paper: Bouanza, J.R.F.K., Ngassa, T.C. and Ndinga, M.M.A. (2018) The Effects of Regulatory Quality on the Pro-Cyclicality of Fiscal Policy in Countries in the Central African Economic and Monetary Community (CA EMC). Modern Economy, 9, 1228-1246.

https://doi.org/10.4236/me.2018.97080

Received: June 19, 2018

Accepted: July 20, 2018

Published: July 23, 2018

Copyright $\odot 2018$ by authors and Scientific Research Publishing Inc. This work is licensed under the Creative Commons Attribution International License (CC BY 4.0).

http://creativecommons.org/licenses/by/4.0/

\begin{abstract}
This article aims to analyze the effects of the regulatory quality on fiscal pro-cyclicality in CAEMC member countries based on the annual panel data for the years 1996 to 2016. To achieve that, we used, on the one hand, the fiscal policy reaction function (Taylor, 2000) as well as institutional quality, and on the other hand, the system-generalized method of moments (system GMM) to empirically understand the effects of the regulatory quality on fiscal pro-cyclicality in CAEMC member countries. Our findings show that the current state of regulatory quality in CAEMC countries promotes the pro-cyclicality of the fiscal policy in this sub-region. In addition, these findings show that the effect of the current state of regulatory quality on fiscal pro-cyclicality is more significant when the regulatory quality is linked to the economic cycle. It is therefore necessary to bring about profound institutional reform in the CAEMC countries in order to redirect the fiscal budget towards counter-cyclicality.
\end{abstract}

\section{Keywords}

Regulatory Quality, Fiscal Pro-Cyclicality, System GMM, CAEMC

\section{Introduction}

Nowadays, the institutional quality bears great significance in an analysis of fiscal cyclicality, in the sense that institutional governance has, over the last decade or so, provided important leverage that can assist in stabilizing economic activity [1]. The debate surrounding the stabilization of economic activity is generally 
based on two types of trends (on the one hand those that support counter-cyclicality and on the other hand those that are opposed to counter-cyclicality).

For authors [2] [3] who are in favor of counter-cyclicality, the implemented policy must mitigate fluctuations in the economy, i.e., the implementation of an expansive policy in a period of economic slow-down and a restrictive policy during a period of growth. For critics of counter-cyclicality, a stabilizing fiscal policy must intensify economic fluctuations, that is, the implementation of a restrictive policy in periods of economic slow-down and an expansive policy during a growth period [4]. Literature shows that pro-cyclicality fiscal policies are found in developing countries while counter-cyclical fiscal policies are observed in developed countries [5].

Several theoretical models attempt to analyze the pro-cyclicality behavior of fiscal policies in developing countries. That is the case with the models of Talvi and Végh [6] and Guillaumont et al. [7]. According to Talvi and Végh [6], the pro-cyclicality nature of fiscal policies in developing countries can be explained by the fact that the tax revenues in these countries are more sensitive to external shocks. According to these authors, when the economic position is in a positive phase, governments often increase expenditure and simultaneously reduce taxes. During a negative phase, not having amassed sufficient savings, governments now reduce expenditure and increase taxes in order to maintain economic activity.

For Guillaumont et al. [7] this approach may be linked to the fact that the principle of multilateral surveillance of fiscal policies, as implemented by the African Unions, is a factor that promotes the pro-cyclicality of government spending particularly in periods of economic recession. This led these authors to consider the modification of the rules of multilateral surveillance in order to encourage conditions that will allow accumulating budgetary surpluses during periods of expansion. Guillaumont et al. [7] perceptions coincide with the IMF's proposal which recommended that countries in the Central African Economic and Monetary Community make an effort to transition from a pro-cyclicality fiscal policy to a countercyclical policy.

Consequently, this line of thinking calls for revisiting the instruments of institutional governance in African Unions to the extent that laws and regulations constitute the foundations to abide by so that the implemented policy would deliver the desired results. One of these instruments is regulatory quality, which is considered as the indicator of the institutional quality that assesses the government's ability to formulate and implement sound policies and regulations that allow and encourage development of the private sector [8]. As such, this indicator plays a fundamental role in the sense that it permits promoting the private sector which is considered to be the key sector able to stimulate economic growth.

This research contributes to this line of thinking, analyzing the effects of reg- 
ulatory quality on fiscal pro-cyclicality in the countries in the Central African Economic and Monetary Community (CAEMC).

In a similar vein, many authors, in particular Frankel et al. [9] demonstrated that the quality of institutional governance could be a solution to enable the transition from pro-cyclicality to counter-cyclicality in fiscal policy. An abundance of literature in the African context mainly deals with the effects of corruption, political stability [10] or even governmental efficacy [1] on the cyclical nature of fiscal policy. According to the information at our disposal, the effects of regulation on the cyclical nature of fiscal policy have apparently not yet been the topic of any specific studies. This observation simultaneously justifies our interest and choice of topic, as well as the scope of this study.

In the context of this study, we argue that regulatory quality, in its current state, amplifies the pro-cyclicality effect of fiscal policies implemented in CAEMC countries. In addition to the introduction and the conclusion, this study covers four points. The first briefly presents the relationship between regulatory quality and economic and fiscal cycles, the second offers a summary of theoretical and empirical studies, the third presents the methodological tools and the fourth presents the findings.

\section{Overview of the Relationship between Regulatory Quality and Economic and Fiscal Cycles}

The economic and financial positions of the Central African Economic and Monetary Community (CAEMC) remain worrisome, due to the fact that it has continuously been downgraded by macroeconomic indicators since 2014 [11]. In fact, according to the International Monetary Fund (IMF) report on common policies in support of reform programs in member countries, the sharp drop in oil prices was at the root of the weak performances of the CAEMC countries, the main consequence of which is the disruption of fiscal policies in this sub-region. According to the same source, revenue shocks as well as accommodating fiscal and monetary policies contribute to reducing the foreign exchange reserves to critical levels causing a significant deficit, escalating from 3.9\% of the GDP in 2004 to $9.3 \%$ in 2016 . This position is confirmed by the final multilateral surveillance report of 2016.

Despite the efforts made by the CAEMC authorities over a period of about ten years, the macroeconomic situation in this sub-region remains worrying. In fact, the macroeconomic position remains characterized by a decline in fiscal and other accounts. Regulatory quality, acknowledged as an indicator of governance, which is supposed to improve the business climate in order to encourage private sector growth as well as job creation, received low scores in all CAEMC countries as demonstrated by the five (5) graphs below:

Graph 1 shows that the lowest regulatory quality score for the CAR was recorded in 2016. Trends in this indicator demonstrate a decrease in scores for the CAR since 2000. This means that the fiscal pro-cyclicality observed in the CAR is 


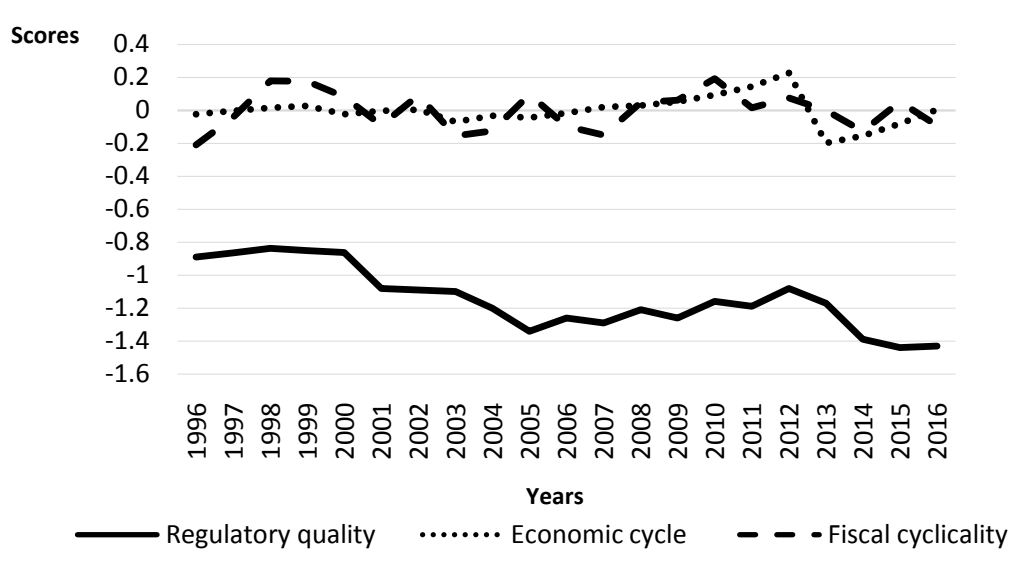

Graph 1. Trends in fiscal cyclicality based on the economic cycle and regulatory quality in the Central African Republic (CAR). Source: Authors, using World Bank and IMF data [11].

partially related to the fact that regulatory quality has not improved.

Cameroon's regulatory quality scores have been consistent since 2002, with scores varying between -0.9 and -0.7 , as shown in Graph 2. Trends in this indicator reflect the efforts by the Cameroonian government aimed at reducing fluctuations in the economy.

Graph 3 shows pro-cyclicality activity marked by strong fluctuations in the economy. Trends in the regulatory quality scores for the Congo appear to have been consistent since 2014, with low scores compared to Cameroon. That means that the fiscal pro-cyclicality observed in the Congo requires an improvement in regulatory quality.

Based on Graph 4, the movements in regulatory quality scores show that prior to 2000, the governance indicator scores in Gabon were positive. That is indicative of a positive position, likely to encourage growth in the private sector and in job creation. However, from 2000 onwards, Graph 4 reflects a negative position with scores that tend to decrease.

As far as Equatorial Guinea is concerned, the regulatory quality scores recorded in Graph 5 shows that this country has achieved the lowest scores of all CAEMC countries. That means that the current regulatory quality cannot contribute to reducing economic fluctuations, but on the contrary, are amplifying them.

The curves shown in Graph 6 demonstrate that for Chad the governance indicator recorded scores similar to those in other CAEMC countries. However, the scores for Chad reflect substantially better regulatory quality scores compared to the rest of the CAEMC countries.

To summarize, the position in CAEMC, as seen in the five graphs, demonstrate that the fiscal policies implemented in the countries of this sub-region appear to be pro-cyclicality as suggested by Bobbo [4]. In fact, Graphs 1-5 show the movements of the economic cycle and fiscal cycle of each country. These 


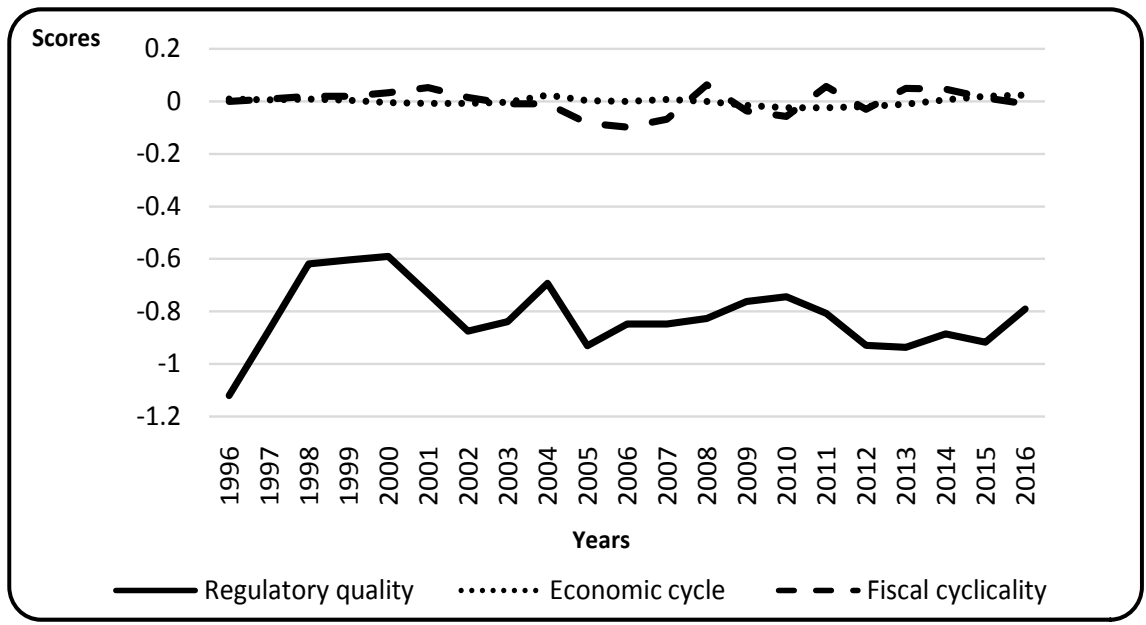

Graph 2. Trends in fiscal cyclicality based on the economic cycle and regulatory quality in CAMEROON. Source: Authors, using World Bank and IMF data [11].

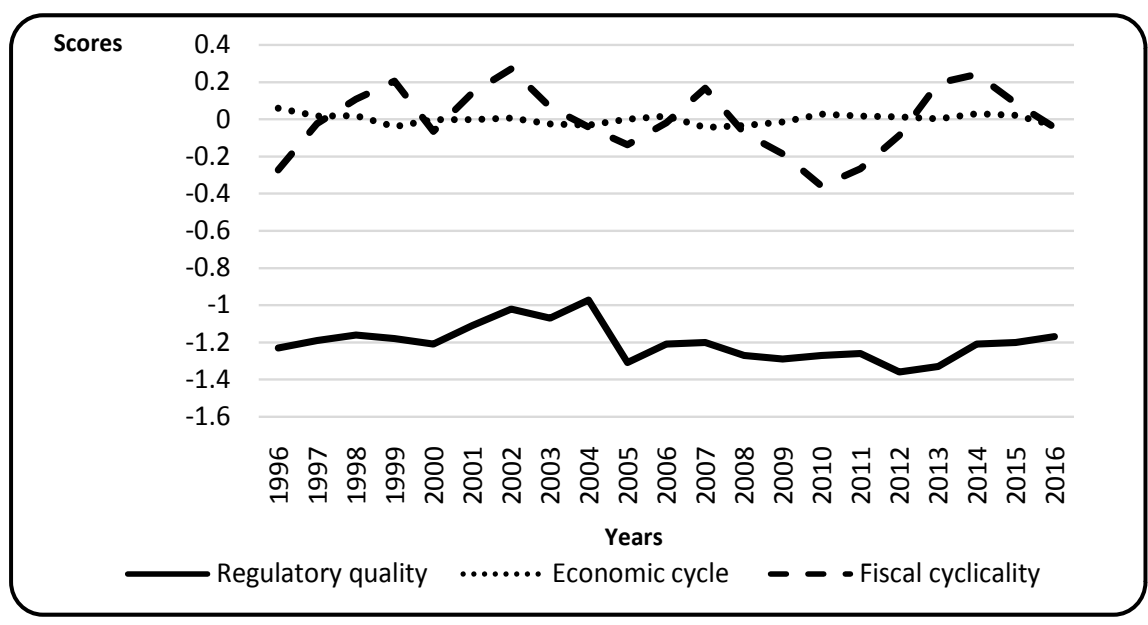

Graph 3. Trends in fiscal cyclicality based on the economic cycle and regulatory quality in the CONGO. Source: Authors, using World Bank and IMF data [11].

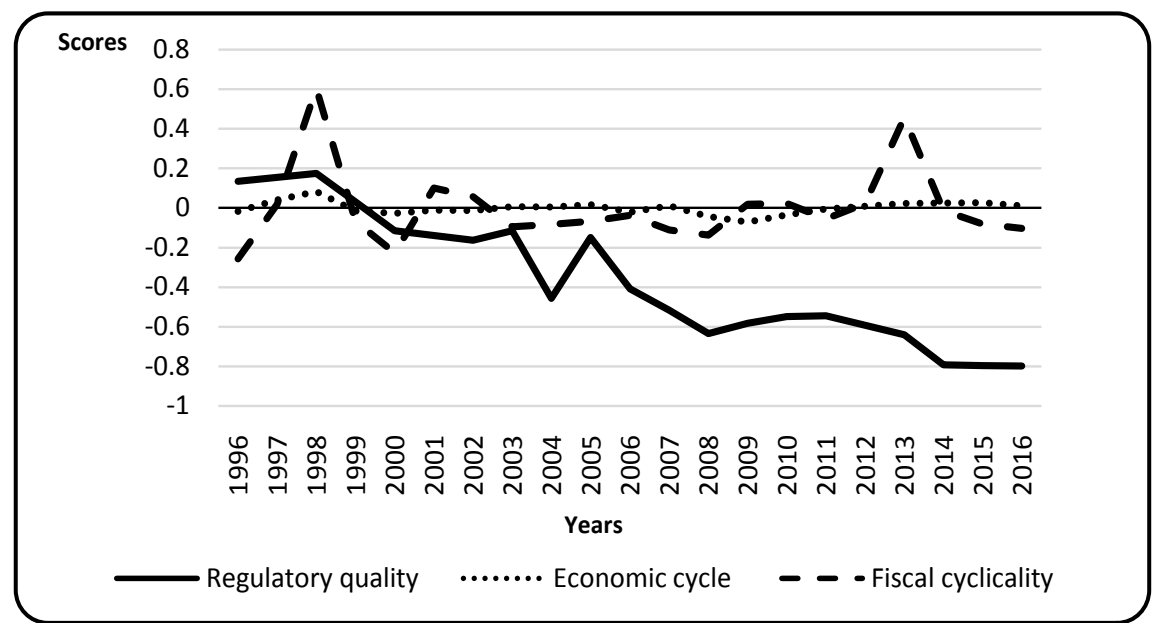

Graph 4. Trends in fiscal cyclicality based on the economic cycle and regulatory quality in GABON. Source: Authors, using World Bank and IMF data [11]. 


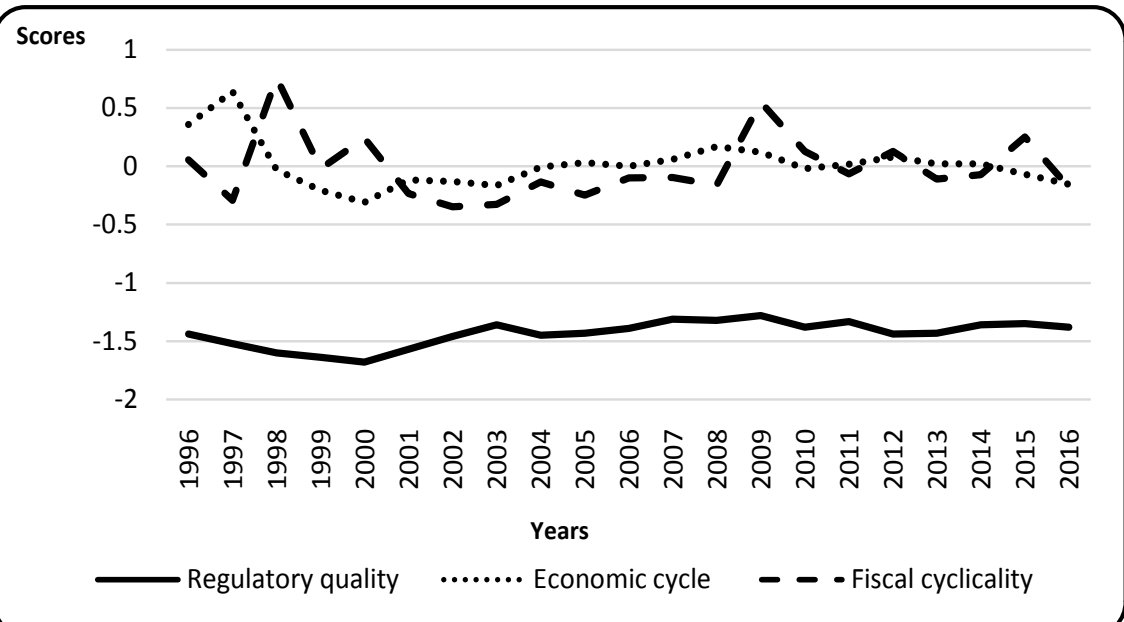

Graph 5. Trends in fiscal cyclicality based on the economic cycle and regulatory quality in EQUATORIAL GUINEA. Source: Authors, using World Bank and IMF data [11].

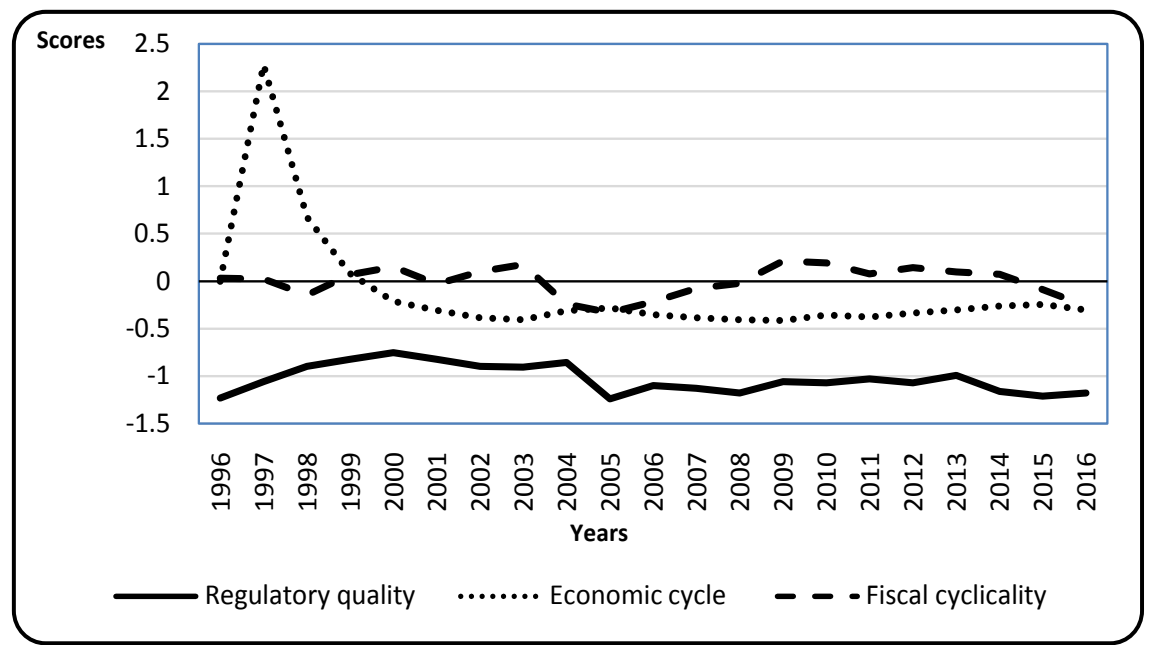

Graph 6. Trends in fiscal cyclicality based on the economic cycle and regulatory quality in CHAD. Source: Authors, using World Bank and IMF data [11].

movements are by and large positive $(+)$, which indicates the existence of a pro-cyclicality fiscal policy. In addition, institutional governance, here expressed by regulatory quality, demonstrates that the scores in this institutional indicator are not likely to reduce the observed economic fluctuations. That implies that at this stage, regulatory quality seems to amplify fiscal pro-cyclicality in this sub-region.

\section{Fiscal Policy Cyclicality in the Literature: What Lessons Can We Learn?}

The issue of fiscal policy cyclicality remains a controversial subject. Hence a great deal of literature, both theoretical and empirical, was dedicated to the topic.

From a theoretical point of view, two arguments can be put forward, i.e. arguments in favor of counter-cyclicality of the active fiscal policy 1) and those 
against counter-cyclicality of the active fiscal policy 2).

\section{1) Arguments in favor of counter-cyclicality of the active fiscal policy}

According to Keynesian theory [2], fixed prices and salaries do not imply a full and immediate adjustment in response to fluctuations in aggregate demand. It follows that a countercyclical active fiscal policy helps the economy to adjust more fully and faster to such fluctuations. In other words, in accordance with its stabilizing function, fiscal policy plays an important role in the stabilization of the business cycle. In that sense, fiscal policy is intended to be counter-cyclical, that is, it must move against the business cycle in order to level it out.

It should also be noted that the leveling off of the business cycle is achieved by reducing tax rates and increasing expenditure during bad times, which leads to an increase in aggregate demand; or by reducing expenditure and increasing fiscal pressures during good times which results in a reduced aggregate demand. By doing so, the Keynesian movement [12] [13] advocate a counter-cyclical active fiscal policy to guarantee economic well-being.

For economists such as Delong and Summers [12] or Blanchard et al. [13], it would be a mistake not to use the instruments of fiscal policy to stabilize the economy. According to the latter, in the absence of a reaction via fiscal policy, the economy is subject to frequent shocks causing inefficient fluctuations in production and employment. Likewise, they support the argument that fiscal policy stabilizes the economy. They also defend a discretionary active fiscal policy to the extent that it offers fiscal authorities the flexibility to react when faced with a number of unforeseen situations.

It should also be emphasized that a stabilizing fiscal policy could also be automatic. To this end, these automatic fiscal measures level out the economic cycle.

2) Arguments in favor of counter-cyclicality of the active fiscal policy

Contrary to Keynes' theory, anti-Keynesian theories of public finance argue that a stabilizing fiscal policy does not have any positive effects on economic activity [14]. In other words, for them a stabilizing fiscal policy would prove to be destabilizing. That is due to the fact that, on the one hand, governments use fiscal policy for electoral purposes and not for the sake of regulation [15]; deficits in public finances would generally be too high, leading to strong accumulation in government debt, and on the other hand, public finance deficits would be detrimental as it would lead to an increase in tax rates, thus causing a decrease in private demand, since agents would anticipate the taxes that they would have to pay subsequently, and lower supply, due to the anticipation of the adverse effects of future taxes (theory of neutrality of fiscal policy, Barro [16]).

Thus, according to supporters of these theories, only a decrease in government spending would be an efficient macroeconomic strategy, in that it allows a decrease in taxes, which would lead to increased supply and demand [14]. In addition, a discretionary fiscal policy is limited not only because of the long delay in reaction but also by its temporal inconsistency [17]. Therefore, according to 
supporters of policies governed by rules, such as Kydland and Prescott [17], it is important to be wary of political processes. In addition, they are convinced that politicians make frequent mistakes in implementing the fiscal policy and what is more, that they often use it to further their own political goals. According to them, this means that only the given rules of fiscal policy can resolve the problem of inconsistency over time.

In summary, it should be noted that the anti-Keynesian theories of public finances, that argue in favor of the reduction of government spending during periods of contraction, cannot be implemented during periods of Keynesian unemployment [14]. These are more applicable in an economy with full employment, or with constrained supply where the State constantly reduces unnecessary government spending, in as far as these have hardly any basis in an economy with a demand deficit where the State temporarily implements a regulatory fiscal policy [14]. Further, the responsiveness offered by a discretionary fiscal policy is deemed inconsistent over time, which gives rise to the rule of fiscal policy in order to improve the management of public finances [17].

From an empirical perspective, the studies presented are mostly those that underline the institutional factors in explaining the cyclical nature of fiscal policy.

The empirical literature dealing with the relationship between institutional governance and the cyclicality of fiscal policy shows that the institutional quality in emerging or developing economies affects the macroeconomic policy and plays a crucial role in the pro-cyclicality of monetary and fiscal policies. Several authors have studied the role of institutions in the pro-cyclicality of monetary and fiscal policies in developed and developing countries. Of these authors, we may cite Frankel et al. [18], Adigozalov et al. [19], Caldéron et al. [20], etc.

The findings of the work by Frankel et al. [18], who worked in emerging and developing countries during the period 1960-2009, indicate that a certain number of developing countries have transitioned from implementing a pro-cyclicality fiscal policy to an anti-cyclical fiscal policy during the course of the first decade of the 2000s. However, they argue that the improvement in the institutional environment index was a major reason for this transformation. Caldéron et al. [21], using a sample of 20 emerging economies and annual data for the period 1990-2003, came to the conclusion that the level of institutional quality plays a key role in the ability of these economies to carry out stabilizing macroeconomic policies. Likewise, they demonstrate that emerging economies that have stable institutions are able to implement the anti-cyclical measures of macroeconomic policies. Adigozalov et al. [19] examined the role of institutional quality in the cyclicality of macroeconomic policies in economies in transition. Based on annual data for the period 1996-2013, they showed that institutional quality plays an important role in their ability to implement an anti-cyclical macroeconomic policy.

Caldéron et al. [20] were concerned with the cyclical properties of fiscal poli- 
cies in Sub-Saharan Africa and tested if the cyclical character can be influenced by the structural and political characteristics of the economy, in particular institutional quality, the political arena, an abundance of resources and the vulnerability of States. Their study supplements the existing literature on Sub-Saharan Africa by using an institutional quality indicator that better captures the economic institutions that support the policy frameworks and simultaneously testing the influence of structural and political factors affecting the cyclical nature of fiscal policy.

Using the annual data for 128 countries over the period from 1970-2013, they came to the conclusion that stronger institutions have more room to maneuvre, which helps to reduce the extent of the pro-cyclicality of the fiscal policy for the majority of countries in the region. These findings call upon African policy makers to intensify institutional reform that will help them to sustainably respond to the problem of pro-cyclicality and to rebuild exchange reserves as a hedge against recessionary crises.

While the findings of the work by Frankel et al. [9], Adigozalov et al. [19] and Caldéron et al. [20] demonstrate that the transitions from pro-cyclicality to counter-cyclicality require an improvement in institutional factors, that was not the case with the work of Itchoko [10] or even Doryn et al. [1]. In fact, the findings of the studies of Itchoko [10] analyzing the influence of institutional variables on the pro-cyclicality of fiscal policy in a sample of 42 countries in Sub-Saharan Africa demonstrated that even when taking institutional factors into account, corruption intensifies the pro-cyclicality of the fiscal policy while a democracy contributes to a decrease in pro-cyclicality.

Like Itchoko [10], Doryń et al. [1] also obtained mixed findings. Examining the relationship between institutional factors and the implementation of the fiscal policy over the course of the economic cycle, using a worldwide sample of 182 countries over the period 1995-2015, Doryń et al. [1] found statistical evidence to support that anti-cyclical fiscal policies are implemented not only by countries with stable institutions, but also by those where the institutional background is weak. However, the breadth of the fiscal policy response to a production gap differs from one country to another. This scope is much wider in advanced countries and less pronounced in developing countries.

This empirical review highlights controversial opinions with regard to the relationship between the institutional quality and the cyclical nature of the fiscal policy. It should also be admitted that the more stable the institutions are, the more likely it is that the fiscal policy will be counter-cyclical and vice versa.

\section{Methodology}

\subsection{Model Specifications and Assessment Procedure}

The cyclicality of the fiscal policy is generally captured by the State's reaction function in formulating its fiscal policy. Drawing on the approach of Taylor [22], the rules of national fiscal policy state that net government spending is, on the 
one hand, influenced by the economic cycle (automatic stabilizers) and on the other hand, by discretionary fiscal policy decisions. In addition, it is necessary to introduce a shock likely to influence net government spending in an unpredictable way. Hence the following formula:

$$
g_{i t}=\beta_{i} y_{i t}+g_{i t-1}+\mu_{i t}^{g}
$$

By taking into account the sustainability constraint on government debt, Equation (1) can be written as:

$$
g_{i t}=\beta_{i} y_{i t}+g_{i t-1}+d_{i t-1}+\mu_{i t}^{g}
$$

In reference to the work of Frankel et al. [18], Caldéron et al. [20] and Doryń et al. [1], institutional quality becomes an important variable in explaining the cyclical behavior of fiscal policy. Hence Equation (2) becomes:

$$
g_{i t}=\beta_{i} y_{i t}+g_{i t-1}+d_{i t-1}+q i_{i t}+\mu_{i t}^{g}
$$

It should be pointed out that $d_{i t-1}$ represents the sustainability constraint on government debt to which the fiscal policy is subject. Several studies use this variable, such as the work of Wyplosz [23], Gali and Perotti [24], Cimodomo [25], Adedeji and Williams [26] and $q i_{i t}$ refers to institutional quality, it is accepted that a country with strong institutions adopts counter-cyclical fiscal policies whereas a country with weak institutions implements pro-cyclicality fiscal policies.

Using this theoretical Formula (3), our equation for general estimation purposes links institutional quality and the cyclicality of the fiscal policy. This equation is as follows:

$$
B_{i t}=\alpha_{i}+\alpha_{0} y_{i t}+\alpha_{1} B_{i t-1}+\alpha_{2} d_{i t-1}+\alpha_{3} q i_{i t}+\alpha_{4} y_{i t} * q i_{i t}+\alpha_{5} x_{i t}+\varepsilon_{i t}
$$

where $B_{i t}$ is the fiscal variable (expenditure, revenues or balance) expressed as a percentile of GDP; $y_{i t}$ corresponds to fluctuations in the output gap. The output gap is calculated as the difference between output and its trend value. $\alpha_{0}$ is the sensitivity of the fiscal policy to fluctuations in the output gap; $\alpha_{0}>0$ and significant, reflects a pro-cyclical fiscal policy (measured by expenditure) and a counter-cyclical fiscal policy (measured by revenue or fiscal balance); $\alpha_{0}<0$ and significant, reflects a counter-cyclical fiscal policy (measured by expenditure) and a pro-cyclicality fiscal policy (measured by revenue or the fiscal balance) and $\alpha_{0}$ non-significant reflects an a-cyclical fiscal policy.

The importance of $\alpha_{0}$ reflects the scale of the cyclicality of the fiscal policy; $B_{i t-1}$ represents the initial (or structural) level of the fiscal policy, it reflects the degree of inertia of the fiscal policy due to the delay in the implementation of new fiscal policy. $\alpha_{1}$ is assumed to be positive, significant and less than the unit; it expresses the existence of the long-term fiscal equilibrium constraint that implies a progressive return to a steady state (stationary variable); $d_{i t-1}$ corresponds to the government debt expressed as a percentile of the GDP. $\alpha_{2}$ is positive and significant and reflects the reason for stabilization of the debt in the implementation of the fiscal policy; $q i_{i t}$ is the variable that captures institutional 
quality. $\alpha_{4}>0$ institutional quality amplifies the cyclical nature of the fiscal policy; $\alpha_{4}<0$ institutional quality reduces the cyclical nature of the fiscal policy and $\alpha_{4}=0$ institutional quality does not affect the cyclical nature of the fiscal policy. $x_{i t}$ represents the control variables that affect the fiscal policy, regardless of changes in output.

Our equation, specifically for estimation purposes, as in the case of Doryń et al. [1] is the following:

$C G E_{i t}=\alpha_{i}+\alpha_{0} y_{i t}+\alpha_{1} C G E_{i t-1}+\alpha_{2} d_{i t-1}+\alpha_{3} R Q_{i t}+\alpha_{4} y_{i t} * R Q_{i t}+\alpha_{5} X_{i t}+v_{t}+\mu_{i t}(5)$

With $C G E_{i t}$ the cyclical component of total government spending. According to Itchoko [10] this corresponds to the gap between total government spending (the observed level of total government spending and its trend level) compared to its trend level. It captures the cyclicality of the fiscal policy. $C G E_{i t-1}$ represents the historical level of the cyclical component of total government spending (discretionary fiscal policy). $R Q_{i t}$ is an indicator of institutional quality, known as regulatory quality. This indicator measures perceptions of the government's ability to formulate and implement sound policies and regulations that will encourage growth in the public sector.

$y_{i t} * R Q_{i t}$ captures the effect of the interaction between regulatory quality and the economic cycle in explaining the nature of the fiscal cyclicality. $X_{i t}$ is a control variable vector consisting of: the fluctuations in the terms of trade (TE), the main source of exogenous shocks on revenue and government spending (thus they affect the fiscal policy); the level of development (GDPC) which makes it possible to control the differences in the levels of development in the actions of the fiscal authorities; inflation (INFLT), according to Guillaumont et al. [7] managing inflation may be an objective of the monetary authorities, just like the regulation of GDP growth (a lower inflation rate is moreover one of the quantitative criteria of multilateral surveillance in CAEMC countries) and financial and economic crises (DUM) so that the financial crisis (2008-2009) and the recent financial crisis can be taken into account in capturing the behavior fiscal authorities' decisions. $v_{t}$ corresponds to the specification of fixed temporal effects, $i$ to individual sizes (of countries), $t$ to the temporal dimension and $\mu_{i t}$ error terms.

Performing an estimation of the fiscal budget cyclicality presents a simultaneity bias between the fiscal budget and economic conditions. In fact, cyclical fluctuations in the GDP are not unrelated to the fiscal policy. This endogeneity bias is evident since a cyclical fiscal policy seeks to influence the economic conditions whilst reacting to its development. To resolve the simultaneity bias, the dynamic panel general method of moments (GMM) that provides an efficient estimation (contrary to the ordinary least squares [OLS] method) was used.

The literature on this method discusses two types of estimators: the Difference GMM (GMM-Diff) estimator and the System GMM (GMM-Sys) estimator. The Difference GMM estimator of Arellano and Bond [27] is based on the first difference of variables and thus eliminates country-specific effects whilst using the 
appropriate levels of lagged values (at the level) as instruments for all potentially endogenous variables. This model provides a consistent estimator specifically for a sufficiently large value of $N$ and a relatively small value of $T$. One of the limitations of this estimator is the asymptotic weakness of precision of the estimator and the instruments that causes considerable bias in finite samples.

Blundell and Blond [28] following Arellano and Bover [29] proposed the System GMM as a solution that involves the simultaneous estimation of the first difference equation associated with the level equation. Their model generates efficient dynamic panel estimators for analyses involving coefficients over short periods ( $T$ is small). The System GMM is much more efficient than the Difference GMM.

Assessing the relevance of this instrumentation method requires the validation of the Sargan/Hansen over-identification tests and the absence of auto-correlation of second-order errors. In addition, unlike the Sargan test, Hansen's test is robust to the heteroskedasticity of error terms.

\subsection{Data}

Annual data on the fiscal policy indicator (total government spending) as well as those on debt, total public debt as a percentile of GDP, and on inflation, captured by the GDP deflator come from the IMF's World Economic Outlook (WEO) database. The cyclical components of total government spending that we have used were obtained by the difference between total government spending compared to its trend level. Additionally, the trend level is obtained using the Hodrick and Prescott filter estimation with $\lambda=100$ as recommended for annual data. Constant GDP data, that facilitated the calculation of output gap fluctuations, as well as those on GDP per capita, were derived from the World Bank's World Development Indicators (WDI) database. The base year for all these indicators was 2010.

To calculate the output gap fluctuations, the same procedure was followed as for the cyclical component of total government spending. The annual data on the terms of trade that were used to calculate the fluctuations in the terms of trade came from the UNCTAD (United Nations Conference on Trade and Development). The calculation of the fluctuations in the terms of trade followed the same procedure as for the cyclical component of total government spending. Annual data on the indicator of institutional quality came from the World Bank's World Governance Indicators (WGI) database, according to the methodology of Kaufmann et al. [30]. As far as the indicator value (DUM) is concerned, we allocated the value 1 to crisis years $(2009,2014,2015$ and 2016) and a value of 0 to other years. The study period ran from 1996 to 2016, thus $126 \mathrm{ob-}$ servations (since we have 6 countries).

The table below gives the main variables used in the context of this study. Table 1 shows a wide spread of values around the mean for all variables except regulatory quality and inflation. In fact, the standard deviation of all distributions 
Table 1. Descriptive statistics (for the six CAEMC countries gathered).

\begin{tabular}{cccccc}
\hline Variable & Comment & Mean & $\begin{array}{c}\text { Standard } \\
\text { Deviation }\end{array}$ & Min & Max \\
\hline $\begin{array}{c}\text { Cyclical component of total government } \\
\text { spending (CGE) }\end{array}$ & 126 & -0.004 & 0.175 & -0.360 & 0.758 \\
$\begin{array}{c}\text { Economic cycle (y0) } \\
\text { Regulatory quality (RQ) }\end{array}$ & 126 & -0.372 & 3.286 & -35.900 & 2.280 \\
Government debt as \% of the GDP (debt) & 126 & -0.997 & 0.387 & -1.680 & 0.175 \\
Fluctuations in the terms of trade (TE) & 126 & 51.468 & 41.112 & 0.000 & 204 \\
GDP per capita (GDPC) & 126 & -0.003 & 0.103 & -0.285 & 0.216 \\
Inflation according to the GDP deflator (inflt) & 126 & 140.150 & 93.201 & 23.800 & 476 \\
\hline
\end{tabular}

Source: Authors, using WDI, WGI and WEO data.

(variables) is higher than the mean obtained except in the case of regulatory quality and inflation.

\section{Estimation Findings and Discussion}

Table 2 [sic] below shows the findings obtained using different estimation methods. (1) and (2) were calculated without considering the robustness related to the correction of heteroskedasticity of errors. In contrast, (3) and (4) take that into account. For our analysis, we focused only on (2) and (4) which appeared most efficient.

According to Table 2, Fisher's probabilities show that the models are globally significant. Based on the Sargan/Hansen tests we cannot reject the hypothesis of the validity of the instruments used. Further, according to the Arellano-Bond tests, acceptance of the absence of AR (2) effects must be noted. This demonstrates that the findings are valid and can be used for interpretation. Referring to those findings essentially derived from the GMM-Sys estimator in (2) and (4), the results appear similar except for the coefficients of regulatory quality and inflation which become significant and that of the debt which loses significance with the GMM-Sys estimator when taking the correction of the heteroskedasticity of the errors into account.

All things being equal elsewhere, the results obtained mean that an increase of 1 percentile point in the economic cycle relates to an increase of about 1.401 points in the cyclical component of total government expenditure (cyclically adjusted). This indicates that the fiscal policy is pro-cyclical. In addition, each percentile point increase in the cyclical component of total government spending in the preceding year increases the cyclical component of total government spending in the ongoing year by approximately 0.79 points. This finding expresses the existence of a long-term steady state fiscal constraint that implies a progressive return to a steady state.

Likewise, each percentile point increase in total government debt in the preceding year, decreased the cyclical component of total government spending by 
Table 2. Estimation findings.

\begin{tabular}{|c|c|c|c|c|}
\hline $\begin{array}{l}\text { Outcome variable: Cyclical component of total } \\
\text { government spending (CGE) }\end{array}$ & (1) & $(2)$ & (3) & (4) \\
\hline & GMM-Diff & GMM-Sys & GMM-Diff & GMM-Sys \\
\hline \multicolumn{5}{|l|}{ VARIABLES } \\
\hline \multirow[t]{2}{*}{ Economic cycle $\left(y_{i t}\right)$} & $2.551^{* * *}$ & $1.401^{* *}$ & $2.551^{* *}$ & $1.401^{*}$ \\
\hline & $(0.666)$ & $(0.599)$ & $(0.722)$ & $(0.673)$ \\
\hline \multirow[t]{2}{*}{ Discretionary fiscal policy $\left(C G E_{i t-1}\right)$} & $0.485^{\star *}$ & $0.790^{* * *}$ & 0.485 & $0.790^{\star * *}$ \\
\hline & $(0.211)$ & $(0.243)$ & $(0.269)$ & $(0.154)$ \\
\hline \multirow[t]{2}{*}{$\begin{array}{l}\text { Sustainability constraint on government debt } \\
\qquad\left(d_{i t-1}\right)\end{array}$} & $-0.002^{\star *}$ & $-0.001^{\star *}$ & -0.002 & -0.001 \\
\hline & $(0.001)$ & $(0.001)$ & $(0.002)$ & $(0.001)$ \\
\hline \multirow{2}{*}{ Regulatory quality $\left(R Q_{i t}\right)$} & 0.249 & 0.071 & 0.249 & $0.071^{* *}$ \\
\hline & $(0.252)$ & $(0.061)$ & $(0.138)$ & $(0.019)$ \\
\hline \multirow[t]{2}{*}{ Interaction terms $\left(y_{i t} * R Q_{i t}\right)$} & $2.232^{* * *}$ & $1.239^{* *}$ & $2.232^{\star *}$ & $1.239^{*}$ \\
\hline & $(0.584)$ & $(0.547)$ & $(0.610)$ & $(0.587)$ \\
\hline \multirow[t]{2}{*}{ Fluctuations in the terms of trade $\left(T E_{i t}\right)$} & $-1.380^{\star * \star}$ & $-0.663^{\star \star}$ & $-1.380^{\star * \star}$ & $-0.663^{\star *}$ \\
\hline & $(0.342)$ & $(0.262)$ & $(0.126)$ & $(0.207)$ \\
\hline \multirow[t]{2}{*}{ GDP per capita $\left(P I B H_{i t}\right)$} & $0.007^{\star * *}$ & -0.000 & $0.007^{*}$ & -0.000 \\
\hline & $(0.002)$ & $(0.000)$ & $(0.003)$ & $(0.000)$ \\
\hline \multirow[t]{2}{*}{ Inflation ( $I N F L T_{i t}$ ) } & $0.002^{*}$ & 0.000 & $0.002^{\star * *}$ & $0.000^{*}$ \\
\hline & $(0.001)$ & $(0.000)$ & $(0.000)$ & $(0.000)$ \\
\hline \multirow[t]{2}{*}{ DUM } & -0.013 & -0.057 & -0.013 & -0.057 \\
\hline & $(0.061)$ & $(0.064)$ & $(0.054)$ & $(0.056)$ \\
\hline \multirow[t]{2}{*}{ Constant } & & 0.101 & & $0.101^{*}$ \\
\hline & & $(0.081)$ & & $(0.044)$ \\
\hline Comments & 114 & 120 & 114 & 120 \\
\hline Number of id & 6 & 6 & 6 & 6 \\
\hline $\operatorname{AR}(1)$ & 0.061 & 0.002 & 0.050 & 0.142 \\
\hline $\operatorname{AR}(2)$ & 0.533 & 0.851 & 0.602 & 0.879 \\
\hline Sargan & 0.233 & 0.177 & 0.233 & 0.177 \\
\hline Hansen & & & 1.000 & 1.000 \\
\hline Prob $>$ F & 0.000 & 0.048 & 0.000 & 0.000 \\
\hline Number of inst & 26 & 28 & 26 & 28 \\
\hline
\end{tabular}

Source: Authors, using panel data standard errors in brackets. ${ }^{* *} \mathrm{p}<0.01,{ }^{* *} \mathrm{p}<0.05,{ }^{*} \mathrm{p}<0.1$.

approximately 0.001 points. This reflects the absence of debt stabilization in the implementation of the fiscal policy. It should also be noted that each point of improvement in regulatory quality results in an increase of approximately 0.07 percentage points in the cyclical component of total government spending for 
the ongoing year. This implies that the current state of regulatory quality encourages the pro-cyclicality of the fiscal policy. In addition, this effect is more pronounced when regulatory quality is related to the economic cycle (1.239). These findings allow us to retain the teaching that the regulatory quality is an enhancer of the pro-cyclicality of fiscal policy in CAEMC member countries.

In fact, the pro-cyclicality nature of the fiscal policy appears to be amplified by regulatory quality in CAEMC member countries. This finding is in line with the work of Adigozalov et al. [19] and Calderon et al. [5], which demonstrate that institutional quality reinforces the pro-cyclicality of fiscal policy in developing countries. These studies suggest that countries with weak institutions tend to increase the degree of pro-cyclicality of fiscal policy. However, the findings of these studies were qualified by Doryń et al. [1] for developing countries with weak institutions. This author showed that these countries adopted small-scale countercyclical policies.

Contrary to Doryń et al. [1], Itchoko [10] came to mixed conclusions, findings that suggest that, on the one hand, corruption reinforced fiscal pro-cyclicality and on the other hand that democracy reduced fiscal pro-cyclicality in Sub-Saharan African countries.

The findings obtained for CAEMC member countries confirm the existence of a link between regulatory quality and the pro-cyclicality of fiscal policies in developing countries, oil producers. The low regulatory quality in these countries will reinforce the pro-cyclicality of fiscal policies; this confirms the point of view put forward at the beginning of this study. The theoretical body of work that supports anti-Keynesian effects suggests that governments, in the background of CAEMC, would use fiscal policy for electoral purposes and not for regulatory purposes, leading to pro-cyclical fiscal policies. The findings of this study also suggest that it is essential to improve institutional quality in CAEMC member countries in order to improve the state of public finances via the adoption of counter-cyclical fiscal policies.

\section{Conclusions and Implication of Economic Policies}

The purpose of this study was to examine the effects of regulatory quality on the pro-cyclicality of fiscal policies in CAEMC member countries. To do that, we used a sample of 126 observations in panel data from six (06) CAEMC member countries. Furthermore, on the one hand, we used the State's reaction function via fiscal policy [22] in addition to institutional quality and on the other hand, with the system generalized method of moments (System GMM). The findings obtained teach an important lesson, namely: regulatory quality in CAEMC member countries is such that it reinforces fiscal policy pro-cyclicality. In addition, the findings obtained suggest that the effect of regulatory quality on fiscal policy pro-cyclicality is more significant when regulatory quality is linked to the economic cycle.

These findings imply that a transition from pro-cyclical fiscal policies to 
counter-cyclical fiscal policies, as recommended by the IMF during the meeting of July 2016 in Malabo, requires the implementation of substantial reforms to improve institutional quality. It is only on this condition that CAEMC member countries can improve the state of their public finances and above all, reduce the vulnerability of their economies to shocks affecting oil prices. Specifically, the improvement of regulatory quality encourages a business climate which in turn allows growth in the private sector and stimulates job creation. All of these contribute to achieving counter-cyclical fiscal policies in the CAEMC member countries.

\section{References}

[1] Doryñ, W., Mackiewicz, M. and Wawrzyniak, D. (2018) The Role of Institutions in Determining the Cyclical Behavior of Fiscal Policy. Lodz Economics, Working Papers No. 2/2018, 28 p.

[2] Keynes, J.M. (1936) Théorie générale de l'emploi, de l'intérêt et de la monnaie. Par-

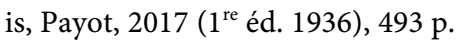

[3] Mankiw, N.G. and Weinzierl, M. (2011) Une exploration de la politique de stabilization optimale. Brookings Papers on Economic Activity, Printemps, 209-272. https://doi.org/10.1353/eca.2011.0003

[4] Bobbo, A. (2016) Régime de change et cyclicité budgétaire dans les pays africains. Revue d'Analyse Économique, 92, 515-544. https://doi.org/10.7202/1040000ar

[5] Calderon, C., Duncan, R. and Schmidt-Hebbel, K. (2012) Do Good Institutions Promote Counter-Cyclical Macroeconomic Policies. Federal Reserve Bank of Dallas-Globalization and Monetary Policy Institute, Working Paper No. 118, 29 p.

[6] Talvi, E. and Végh, C. (2005) Tax Base Variability and Procyclical Fiscal Policy in Developing Countries. Journal of Development Economics, No. 78, 156-190. https://doi.org/10.1016/j.jdeveco.2004.07.002

[7] Guillaumont, J., Tapsoba, S. and Sylviane (2009) Pro cyclicité de la politique budgétaire et surveillance multilatérale dans les unions monétaires africaines. Working Papers n 200904 from CERDI, 49 p.

[8] Mondiale, B. (2017) Rapport sur le développement dans le monde 2017: La gouvernance et la loi. Banque mondiale, Washington DC, $78 \mathrm{p}$.

[9] Frankel, N., Vegh, C. and Vuletin, G. (2011) On Graduation from Fiscal Pro-Cyclicality. NBER, Working Paper 17619, 35 p.

[10] Itchoko, M.M.M.N. (2017) Institutions and Pro-Cyclicality of Fiscal Policy in Sub Saharan Africa. Economics Bulletin, 37, 1365-1380.

[11] FMI (2017) Rapport des services du FMI sur les politiques communes à l'appui des programmes de réforme des pays members CEMAC (2017). Rapport définitif de surveillance multilatérale 2016 et perspectives, $78 \mathrm{p}$.

[12] Delong, J.B. and Summers, H.L. (2012) Fiscal Policy in a Depressed Economy. Brookings Papers on Economic Activity, 44, 233-297. https://doi.org/10.1353/eca.2012.0000

[13] Blanchard, O., Cerutti, E. and Summers, L. (2015) Inflation and Activity-Two Explorations and their Monetary Policy Implications. FMI, Working Paper, 29 p.

[14] Creel, J., Ducoudré, B., Mathieu, C. and Sterdyniak, H. (2005) Doit-on oublier la politique budgétaire? Une analyse critique de la nouvelle théorie anti-keynésienne 
des finances publiques. Revue de l'OFCE, No. 92, 43-97.

https://doi.org/10.3917/reof.092.0043

[15] Buchanan, J.M. and Tullock, G. (1962) The Calculus of Consent. University of Michigan Press, Ann Arbor. https://doi.org/10.3998/mpub.7687

[16] Barro, R.J. (1974) Are Government Bonds Net Wealth? Journal of Political Econo$m y$, 82, 1095-1118. https://doi.org/10.1086/260266

[17] Kydland, F. and Prescott, E. (1977) Rules Rather than Discretion: The Time Inconsistency of Optimal Plans. Journal of Political Economy, 85, 473-492.

https://doi.org/10.1086/260580

[18] Frankel, J.A., Vegh, C.A. and Vuletin, G. (2013) On Graduation from Fiscal Procyclicality. Journal of Development Economics, 100, 32-47. https://doi.org/10.1016/j.jdeveco.2012.07.001

[19] Adigozalov, S. and Rahimov, V. (2015) Institutional Quality, Cyclicality of Macroeconomic Policies and the Effects of Macroeconomic Shocks: Evidence from Transition Economies. Graduate Institute of International and Development Studies International Economics Department, Working Paper, Series HEIDWP0023-2015, 25 p.

[20] Calderón, H. and Nguyen, C. (2016) The Cyclical Nature of Fiscal Policy in Sub-Saharan Africa. Journal of African Economies, 25, 548-579. https://doi.org/10.1093/jae/ejw007

[21] Calderon, C., Duncan, R. and Klaus, S. (2004) Institutions and Cyclical Properties of Macroeconomic Policies. Central Bank of Chile, Working Paper 285, 28 p.

[22] Taylor, J.B. (2000) Reassessing Discretionary Fiscal Policy. Journal of Economic Perspectives, 14, 21-36. https://doi.org/10.1257/jep.14.3.21

[23] Wyplosz, C. (2002) Fiscal Policy: Institutions versus Rules. CEPR Discussion Papers 3238, CEPR Discussion Papers, 40 p.

[24] Gali, J. and Perrotti, R. (2003) Fiscal Policy and Monetary Integration in Europe. NBER Working Paper, No. 9773, 45 p.

[25] Cimadomo, J. (2005) Le pacte de stabilité a-t-il renforce la pro cyclicité de la politique budgétaire. La lettre du CEPII (Centre d'Etudes Prospectives et d'Informations Internationales), No. 247, 4 p.

[26] Adedeji, O. and Williams, O.H. (2007) Fiscal Reaction Functions in the CFA Zone: An Analytical Perspective. IMF Working Papers 07/232, International Monetary Fund, $21 \mathrm{p}$.

[27] Arellano, M. and Bond, S. (1991) Some Test of Specification for Panel Data: Monte Carlo Evidence and an Application to Employment Equations. Review of Economic Studies, 58, 277-297. https://doi.org/10.2307/2297968

[28] Blundell, R. and Bond, S. (1998) Initial Conditions and Moment Restrictions in Dynamic Panel Data Models. Journal of Econometrics, 87, 115-143. https://doi.org/10.1016/S0304-4076(98)00009-8

[29] Arellano, M. and Bover, O. (1995) Another Look at the Instrumental Variable Estimation of Error-Components Models. Journal of Econometrics, 68, 29-51. https://doi.org/10.1016/0304-4076(94)01642-D

[30] Kaufmann, D., Kraay, A. and Mastruzzi, M. (2010) The Worldwide Governance Indicators: Methodology and Analytical Issues (September 2010). World Bank Policy Research Working Paper, No. 5430, 31 p. 


\section{Annexes}

Estimation findings for GMM-Sys estimator without Hansen test.

\begin{tabular}{|c|c|c|c|}
\hline $\begin{array}{c}\text { Outcome variable: Cyclical component of total government } \\
\text { spending (CGE) }\end{array}$ & & & \\
\hline VARIABLES & Coef & $\mathrm{t}$ & $P>|t|$ \\
\hline Economic cycle $\left(y_{i t}\right)$ & 1.401 & 2.340 & 0.021 \\
\hline Discretionary fiscal policy $\left(C G E_{i t-1}\right)$ & 0.790 & 3.250 & 0.002 \\
\hline Sustainability constraint on government debt $\left(d_{i t-1}\right)$ & -0.001 & -2.160 & 0.033 \\
\hline Regulatory quality $\left(R Q_{i t}\right)$ & 0.071 & 1.170 & 0.244 \\
\hline Interaction terms $\left(y_{i t} * R Q_{i t}\right)$ & 1.239 & 2.270 & 0.025 \\
\hline Fluctuations in the terms of trade $\left(T E_{i t}\right)$ & -0.663 & -2.530 & 0.013 \\
\hline GDP per capita $\left(P I B H_{i t}\right)$ & -0.000 & -0.440 & 0.660 \\
\hline Inflation ( $I N F L T_{i t}$ ) & 0.000 & 1.520 & 0.132 \\
\hline DUM & -0.057 & -0.900 & 0.372 \\
\hline Constant & 0.101 & 1.250 & 0.215 \\
\hline Comments & & 120 & \\
\hline Number of id & & 6 & \\
\hline Number of inst & & 28 & \\
\hline $\operatorname{AR}(1)$ & & -3.170 & 0.002 \\
\hline $\operatorname{AR}(2)$ & & 0.190 & 0.851 \\
\hline Sargan & & & 0.177 \\
\hline Prob $>$ F & & & 0.048 \\
\hline
\end{tabular}

Source: Authors, using panel data.

Estimation findings for GMM-Sys estimator with Hansen test.

\begin{tabular}{cccc}
\hline $\begin{array}{c}\text { Outcome variable: Cyclical component of total government } \\
\text { spending (CGE) }\end{array}$ & & & \\
\hline VARIABLES & Coef & $\mathrm{t}$ & $\mathrm{P}>|\mathrm{t}|$ \\
Economic cycle $\left(y_{i t}\right)$ & 1.401 & 2.080 & 0.092 \\
Discretionary fiscal policy $\left(C G E_{i t-1}\right)$ & 0.790 & 5.110 & 0.004 \\
Sustainability constraint on government debt $\left(d_{i t-1}\right)$ & -0.001 & -1.440 & 0.210 \\
Regulatory quality $\left(R Q_{i t}\right)$ & 0.071 & 3.680 & 0.014 \\
Interaction terms $\left(y_{i t} * R Q_{i t}\right)$ & 1.239 & 2.110 & 0.088 \\
Fluctuations in the terms of trade $\left(T E_{i t}\right)$ & -0.663 & -3.200 & 0.024 \\
GDP per capita $\left(P I B H_{i t}\right)$ & -0.000 & -0.680 & 0.524 \\
Inflation $\left(I N F L T_{i t}\right)$ & 0.000 & 2.070 & 0.093 \\
DUM & -0.057 & -1.020 & 0.356 \\
Constant & 0.101 & 2.300 & 0.070 \\
Comments & & 120 & \\
\hline
\end{tabular}




\section{Continued}

\begin{tabular}{ccc}
\hline Number of id & 6 & \\
Number of inst & 28 & \\
AR (1) & -1.470 & 0.142 \\
AR (2) & 0.150 & 0.879 \\
Sargan & & 0.177 \\
Hansen & & 1.000 \\
Prob $>$ F & & 0.000
\end{tabular}

Source: Authors, using panel data. 